\title{
ADOLESCENTS' KNOWLEDGE, BELIEFS AND EXPERIENCES REGARDING SEXUAL PRACTICES
}

\section{Dr LB Khoza}

D Litt et Phil

Associate Professor, University of Venda for Science and Technology

Correspondence: bkhoza@univen.ac.za

Keywords: sexual practice; adolescents; condom use; safer sex practice; risky sex practice

\begin{abstract}
Unwanted or unprotected pregnancies and sexually transmitted infections among the youth are the result of engaging in unprotected sexual behaviour. The purpose of this qualitative study was to explore and describe what adolescents view as being safer or risky sex practice, and to differentiate between their sexual practice by gender and sexual experience. Non-probability purposive sampling was used to obtain a sample comprising of 12 females and 15 males of ages ranging between 15 and 18 years. Results indicated that the adolescents were able to identify what are regarded as safer or risky sexual practices. However, when expressing their lived experiences of sexual practices, the participants were still engaging in risky sexual behaviour. In conclusion there is a need to acknowledge that young people are sexual beings. The focus of sexuality education should shift from that of disease prevention instead to looking at the more socially-oriented health-enhancing behaviour such as teaching adolescents about sexual development, sexual behaviour and its possible negative outcomes, sexual abuse, gender issues and power relations and other nonsexual ways of showing affection.
\end{abstract}

\section{OPSOMMING}

Ongewenste of onbeskermde swangerskappe en seksueel-oorgedraagde infeksies onder die jeug is die gevolg van onbeskermde seksuele gedrag. Die doel van hierdie kwalitatiewe studie was om dit wat adolessente beskou as veiliger of meer gewaagde seksuele praktyk, te verken en te beskryf en om tussen seksuele praktyke volgens geslag en seksuele ondervinding te onderskei. Nie-waarskynlikheids, doelgerigte steekproeftrekking is gebruik om ' $n$ steekproef te bekom wat bestaan het uit 12 vroulike en 15 manlike deelnemers, tussen 15 en 18 jaar oud. Die resultate het getoon dat adolessente by magte was om dit te identifiseer wat as veiliger en meer riskante seksuele gedrag beskou kan word. Dit terwyl die deelnemers hulle beleefde ondervinding van seksuele praktyke beskryf het, het dit duidelik geblyk dat hulle steeds riskante seksuele gedrag beoefen het. Daar is tot die gevolgtrekking gekom dat daar erkenning gegee moet word aan die feit dat jong mense seksuele wesens is. Die fokus van seksualiteitsonderrig behoort te verskuif van siektevoorkoming, na gedrag wat meer sosiaal-georiënteerd is en wat op gesondheidsverbetering gerig is soos om adolessente te onderrig aangaande seksuele ontwikkeling, seksuele gedrag en die moontlike negatiewe gevolge daarvan, seksuele misbruik, geslagsvraagstukke en magsverhoudings, en nie-seksuele maniere om liefde en toegeneentheid te toon. 


\section{INTRODUCTION AND BACKGROUND OF THE PROBLEM}

Sexuality lessons are first learned from parents who have the primary responsibility for providing sexuality education for their children (Synovitz, Herbert, Kelley \& Carlson, 2002:163-173). As a child starts primary and secondary schooling, the responsibility expands to engage teachers. The community as well has an obligation to provide sexuality education programmes.

Sexuality is a lifelong process that encompasses the biological, emotional, psychological, and social domains, and is a natural and healthy part of living. Proper sexuality education assists the youth, teenagers and adolescents in understanding sexuality, engendering a positive view of sexuality and helping them to make responsible decisions regarding their sexual health (Synovitz et al. 2002:163-173).

According to the World Health Organization (WHO) there are more than $50 \%$ new Human Immunodeficiency Virus (HIV) infections occurring among the 15-24 yearolds. Approximately 17 million girls younger than 20 years give birth each year in developing countries (Silberschmidt \& Rasch, 2001:1815-1816). Substantial numbers of youth are still engaging in high-risk sexual practice such as unprotected sexual intercourse. A recent WHO global review of research exploring sexual practices concluded that the most successful approaches are those which do not focus exclusively on the cognitive processes of the individual but also take into account the social world in which the behaviour happens (Mitchell, Debbie \& Watson, 2000:262-265).

Unwanted or unexpected pregnancies and sexually transmitted infections (STIs) among the youth are the result of engaging in unprotected sexual behaviour. It could be assumed that lack of sexual knowledge about the use of condoms or contraceptives, the effects of HIV and other STIs contribute to unprotected sexual behaviour. According to Ehlers (2003:19-20) adolescent mothers in South Africa provided reasons for not using contraceptives such as, ignorance about contraceptives, fear to go to the clinic, fear of picking up weight and opposition of their boyfriends regarding their use of contraceptives. A similar problem affected adolescents in Texas, in the United States of America (USA). Adolescents on the pill or injectable hormonal contraceptives worried about gaining weight (Wilcox, Baird \& Weinberg, 1999:365). Factors that impede the use of condoms by the youth in South Africa included lack of perceived risk, peer norms, condom availability, adult attitudes to condoms and sex, and gender power relations (Ehlers, 2003:20).

According to Dickson-Tetteh and Foy (2001:2) the majority of youth in South Africa engage in sexual activities in their mid-teens. Approximately 11 million episodes of STIs occur each year in South Africa, with over $50 \%$ of these infections occurring among adolescents between the ages of 15-20 years. The high incidence of STIs might probably be an indication of the high incidence of youth involvement in sexual intercourse

Mitchell et al. (2000:262-265) indicate that despite the national policy that supports the development of a comprehensive school-based HIV/AIDS strategy in Australia, substantial numbers of the youth are still engaging in high-risk sexual practices, such as unprotected sexual intercourse with casual partners. In the USA, despite sexuality education programmes introduced in tertiary institutions, risky sex behaviour and prevalence of STIs are at an alarming level. Researchers in the USA have described outcomes associated with adolescent sexual behaviour to be an epidemic (Nahom, Wells, Gilmore, Hoppe, Morrison, Archibald, Murowchick, Wilsdon \& Graham, 2001:153-159).

According to Lehana and Van Rhyn (2003:23), providing sexuality education to adolescents is taboo in Lesotho. Substantial numbers of youth (13-19 years of age) are sexually active. When sexual activity begins, most adolescents lack accurate knowledge about reproduction and sexuality.

\section{STATEMENT OF THE PROBLEM}

Despite the sexuality education programme introduced at schools and the National Adolescent Friendly Clinic Initiative (NAFCl) programme that is aimed at improving the sexual behaviour of adolescents in the Limpopo Province of South Africa, teenage pregnancy, episodes of STIs and HIV are still reported at an alarming rate (Dikson-Tetteh \& Foy, 2001:2; Ehlers \& Khoza, 2001:4).

The incidences of teenage pregnancy among school going adolescents at the Greater Tzaneen municipal- 
ity of the Limpopo Province have been reported by principals to be increasing at an alarming rate. One particular school requested the nearby health centre to intervene by providing sexuality education to learners. Serving as a research partner with the coordinator of $\mathrm{NAFCl}$ programme rendered at the health centre, there was a felt need that research should be done to explore the adolescents' knowledge, beliefs and experiences regarding safer or risky sex practice. The findings of the research could inform the coordinator on the learning needs of the adolescents attending the NAFCl programme.

The following central questions were posed:

- What is your understanding of safer sex practice?

- What is your understanding of risky sex practice?

\section{PURPOSE AND OBJECTIVES OF THE STUDY}

The purpose and objectives of the study were to explore and describe the adolescents' knowledge, beliefs and experiences regarding safer or risky sex practice, and to differentiate by gender and sexual experience in adolescent sexual practice:

- $\quad$ to determine what the adolescents view as being safer sex practices;

- $\quad$ to determine what the adolescents view as being risky sex practices; and

- $\quad$ to determine adolescent sexual practices by gender and sexual experience.

\section{DEFINITION OF THE KEY CONCEPTS}

Adolescent: An adolescent is defined as an individual between the ages of 10-19 (Dickson-Tetteh \& Foy, 2001:38). The study refers to both females and males between the ages of 15-18, attending the secondary school.

Sex practice: The study refers to what adolescents regard as safer or risky practice when engaging in sexual intercourse.

\section{RESEARCH METHOD}

The study followed an exploratory, descriptive, qualitative approach. According to Burns and Grove (1997:27), qualitative research is a way of gaining insight through discovering meanings. It is a way of exploring the depth, richness and complexity inherent in the phenomenon. The study attempted to describe what adolescents view as being either safer or risky sex practices.

\section{Population and sampling}

The accessible population of the study was adolescents between the ages of 15 and 18 years at the Greater Tzaneen Municipality of Limpopo Province, South Africa. Dickson-Tetteh and Foy (2001:38) regard an adolescent as an individual between the ages of 10-19. The sample of the study was obtained during Love Life soccer games held at the Nkowankowa stadium in 2003. Letters of invitation were issued to those who were willing to be subjects of the study and who met the criteria for selection. Both male and female adolescents were required to be subjects of the study.

The letter of invitation included the purpose of the study, date, venue and time for the meeting, ethical measures that would be taken such as participant's right to confidentiality, obtaining informed consent, privacy and anonymity, and that they would be given an incentive in the form of a pocket diary for their participation.

Non-probability purposive sampling was used. As the qualitative researcher using this method did not know in advance how many subjects would be needed, 60 letters were issued out. Issuing 60 letters was regarded to be sufficient enough because the researcher was going to use focus group interviews. Furthermore, the method was chosen because the researcher targeted those who were willing to participate in the study. The researcher and other two participants namely one female and one male participant who met the set criteria, distributed letters of invitation to others who were willing to participate by communicating their knowledge and lived experiences of sexual practice. The sample criteria stated that participants had to be:

- $\quad$ youth between 15 and 18 years of age;

- $\quad$ sexually active;

- $\quad$ attending secondary school;

- $\quad$ residing in Nkowankowa township and the nearby villages within a radius of less than six kilometres in order to avoid travelling 
costs; and

$\bullet$

willing to participate in the youth programmes offered at the local clinics and health centres as volunteers for peer education.

\section{DATA COLLECTION}

In-depth focus group interviews were conducted by the researcher using a tape recorder to record the information. The interviews comprised of three sessions as follows:

Session 1: a focus group discussion with 12 female participants

Session 2: a focus group discussion with 15 male participants

Session 3: a focus group discussion with five female and five male participants who had volunteered to participate further. This session was intended to explore issues of gender differences with regard to their sexual knowledge and sexual practices.

Each session lasted for 40-45 minutes, and was guided by data saturation since the participants showed interest on the topic of study and shared their knowledge, beliefs and experiences regarding sex practice freely. A classroom setting for conducting interviews was prepared at one particular pre-school in the Nkowankowa Township. The participants were orientated on how the proceedings would be conducted (Polit \& Hungler, 1987:370). Facilitating communication techniques such as minimal responding, clarification and rephrasing to encourage the subjects to speak openly and freely were utilised (Minichiello, Aroni, Timewell \& Alexander, 1991). Field notes were jotted down as the participants responded to the questions posed. The participants were interviewed in Xitsonga, because it was the language of their choice. The participants were asked to respond to the following two central questions:

- What is your understanding of safer sex practices?

- What is your understanding of risky sex practices?

The principles outlined by Lincoln and Guba (1985:290) were followed to ensure trustworthiness of the study. Credibility was achieved through spending time informally with each group of participants to gain their confidence. They were instructed to turn the tape recorder off if they were feeling uncomfortable to be recorded. Participants were purposively sampled and entering into third session of interviewing both the females and male participants simultaneously prolonged engagement, increased probing of information and enhanced data saturation. Using two different groups by gender, tape recordings as well as written dialogues during interviews increased the confirmability. Transferability was ensured by complete description of the methodology. In-depth literature control on the topic of study and verbatim quotes cited in the findings will enable readers to do self-assessment of their own sexual behaviour.

\section{METHOD OF DATA ANALYSIS}

The taped interviews were transcribed verbatim and translated into English. The translated data was given to a language expert to confirm whether the translated data retained the same meaning as that solicited from the participants. The two central questions were used as the major themes of the data analysis. Guided by Tech's method of data analysis (Creswell, 1994:155), information provided by the participants was classified according to the themes denoting safer or risky sex practices. The most descriptive word for the expressed sexual behaviour pertaining to the sub-themes was identified as sub-themes (Table One).

\section{FINDINGS}

Of the 60 participants invited, 27 adolescents attended the interviewing sessions. Twelve participants were female and 15 were male. Female participants ranged between the ages of 16 and 18 years, whereas males were between 15 and 18 years of age. The sample was regarded to be adequate because a focus group interview requires about $5-15$ people whose opinions and experiences are requested simultaneously (Brink, 1996:159). At the interviews the letter of invitation was read aloud, the participants were informed that participation to the study was not mandatory, and that they had the right not to participate according to the human subject view. The participants were assured that they would not be coerced into answering questions. All participants met the criteria set. The risk-benefit ratio was explained to the participants namely that the study was concerned with the potential contribution of knowl- 
edge that was of practical value to the community. Participants were assured that no harm would occur to them as a result of participation in the study because anonymity and confidentiality would be maintained (Brink, 1996:40-43).

\section{DISCUSSION OF RESULTS}

\section{Safer sex practice}

Participants, both female and male, indicated that people should be educated to protect themselves against HIV and other STIs by using condoms, being faithful to one partner, waiting and abstaining from sexual activities until getting married, and avoiding starting sexual activities at an early age, that is younger than 18 years. It was suggested by the males that a girl must wait until old enough to make sound judgements about her sexual life. They further indicated that engaging in sexual activities before marriage was something that was not bad, provided both partners had been tested HIV negative. Female participants emphasised that both partners should have HIV/AIDS counselling and be tested before they started sexual activities. Females felt that men can never be trusted because they like having many girlfriends. Despite these identified elements of safer sex practices by participants, females indicated that they did not have knowledge of a female condom and no one had ever seen it.

When asked about the methods of contraception, seven female participants indicated that they were not using contraceptives because their boyfriends were using condoms. They would, however, prefer using the pill

Table 1: Major themes and sub-themes of the adolescents' knowledge, beliefs and experiences regarding sex practice

\begin{tabular}{|c|c|}
\hline MAJOR THEMES & SUB-THEMES \\
\hline Safer sex practices & $\begin{array}{l}\text { 1.1 Use of condoms } \\
\text { 1.2 Abstinence from sexual activities } \\
\text { 1.3 Use of contraceptives by girls } \\
\text { 1.4 Respect of cultural values and beliefs } \\
\text { 1.5 Faithfulness } \\
\text { 1.6 HIV counselling and testing } \\
\text { 1.7 Non-penile penetration method }\end{array}$ \\
\hline Risky sex practices & $\begin{array}{ll}2.1 & \text { Unprotected sex } \\
\text { 2.2 } & \text { Teenage pregnancy } \\
2.3 & \text { Abortions } \\
2.4 & \text { Rape } \\
2.5 & \text { Prostitution } \\
2.6 & \text { Contraceptives } \\
\text { 2.7 } & \text { Starting sex at an early age } \\
2.8 & \text { Homosexuals } \\
\text { 2.9 } & \text { Having sex with a widow } \\
\text { 2.10 } & \text { Poor hygiene } \\
\text { 2.11 } & \text { Many sexual partners } \\
\text { 2.12 } & \text { Having sex with a girl menstruating }\end{array}$ \\
\hline
\end{tabular}


because they had learned from friends that using injections made a person gain weight and also experience loss of libido. Female participants did not have knowledge of emergency contraceptives, what they were and when to use them. Ehlers (2003:21) indicated that 40 out of 60 adolescent mothers in Tshwane, South Africa, did not know about the availability of emergency contraceptives to be taken within 72 hours after unprotected sex. A survey conducted in the Limpopo Province reported that $73 \%$ of 93 student nurses had no knowledge of emergency contraceptives despite being health care providers (Netshikweta, 1999:96).

Only five male participants said they were using condoms regularly when they engaged in sexual intercourse. Others said that they seldom used condoms, only when they did not trust the girl or when she was menstruating. Prevention of unwanted pregnancy as a motivation for the use of condoms was not mentioned in the discussion. In some urban areas in the USA, teenagers are becoming less likely to engage in behaviour that could put them at risk of contracting HIV and other STIs. Sexually active students in five cities of the USA reported substantial increases in their use of condoms during intercourse. Despite these improvements, many adolescents remain at risk of HIV infection (Synovitz et al. 2002:163-173).

In the focus group discussion where male and female participants were interviewed together, females referring to boys, emphasised that having sex without a condom was the worst criminal offence because boys flitted around and spread HIV and STIs. One female participant indicated that she had broken off the affair with her boyfriend because he did not want to use a condom. She said the boyfriend used to say "having sex with a condom is like eating a banana which is not peeled".

A study by Peltzer (2001:55) found that the most common reasons for not using condoms were "I do not have the AIDS virus"; "I thought I was safe"; and "I was with my steady partner". Males scored higher than females on reasons for not using condoms and they had more knowledge than females about correct male condom use. This finding is similar to that found in other studies. Nahom et al. (2001:153-158) in the USA found that females were less likely than males to follow through on intentions to consistently use condoms and that males had more positive intentions to use condoms with steady partners, though not with casual partners. Females perceived less pressure for sex and more support for waiting than did males.

Synovitz et al. (2002:163-173) indicated that females were higher in overall knowledge and on the topics of contraception, and they were more cautious than boys in their sexual practices. However, in order to validate the impact of sexuality education that the participants had received, a test performance ought to be conducted on aspects such as anatomy, reproductive health, contraception, HIV/AIDS and STIs, abortions, gender issues, sexual disorders and pregnancy.

Various studies have indicated that sexuality education has been found to be successful in promoting abstinence, decreasing sexuality activities, increasing use of safer sexual practices, increasing teenage sexual responsibility, increasing sex-related knowledge, aiding youth towards more responsible sexual decisionmaking, delaying the age at which first sexual intercourse occurred and not encouraging earlier or increased sexual activity or the number of partners (Synovitz et al. 2002:163-173; Kirby, 1997:216).

\section{Risky sex practices}

The data obtained showed that the participants were aware of some of the issues around "risky sex practices". Both the male and the female participants indicated what is regarded as risky sex practice to be unprotected sexual intercourse, teenage pregnancy, abortion, rape, prostitution, contraceptives, starting sex at an early age, homosexuality, having sex with a widow, poor hygiene, many sexual partners, lack of knowledge of HIV status and having sex with a girl when menstruating. Male participants mentioned that rape was an addictive behaviour caused by failure to meet the sexual demands in relationships. One male said, "If you are a flop in bed, it is obvious girls will turn you down and you will start raping them". Furthermore, males indicated that females enticed boys by wearing mini-skirts and exposing their bodies. This was another reason for the increase in rape among girls. Female participants indicated that boys were rapists because they engaged in using drugs and alcohol, and the majority of boys raped with the intention of spreading HIV/AIDS and STIs. One female participant said, "Boys are evil-hearted; they do 
not want to die alone. They will make it a point that they date many innocent girls in order to spread the virus".

In Session Three both male and female participants shared similar sentiments regarding factors leading to starting sexual activities at an early stage such as group conformity, competition, adolescent stage of curiosity, unemployment and irresponsible parents. One male participant said, "You cannot resist after seeing a pornographic movie. You just feel you must practise what you saw on television". Male participants emphasised that group conformity and competition were the major problems whereas girls indicated that they were acting out of curiosity.

Aspects of cultural beliefs emerged during the discussions. Both groups of participants mentioned beliefs that if a boy or a girl were regarded as being "impure", they would need traditional cleansing. Boys indicated that having sex with a widow was "taboo", because she was still hot; as a result the man would suffer a condition called "Makhume". This condition was explained by them as characterised by a distended abdomen, swollen legs, "swollen tool box" referring to the scrotum, persistent cough, breathlessness, sometimes inability to pass urine and eventually the man would die.

Female participants indicated that there was no harm to having sex with a girl who had had a safe abortion, because in the hospital the person's womb would be cleaned. All the "dirty stuff", implying retained products, will have been scraped off. Males became lethargic and indicated that sleeping with a woman who had undergone abortion was like committing suicide. Males believed that the woman was highly infectious and once a man got infected there was no medical cure except going to the traditional healer for cleansing. They expressed that nowadays very few "Inyangas" were able to treat this condition successfully. One male described the condition characterised by an abnormally hot body, inability to pass urine or passing urine with clots, confusion, a gaping and pulsating fontanelle and distended blood vessels. This could imply that participants had an idea that having sexual intercourse with a female who had had a septic abortion could infect a man.

The findings may also be a result of the difference in the socialisation process of boys and girls. Gender differences in sexuality experiences, especially in the black communities, stemmed from societal norms and values that had been infused in young people by parents and the community. For instance, it was more socially acceptable for boys to desire sex with no recriminations, while girls were encouraged to stay virgins as long as possible. In conclusion, there is a need for adolescents to improve their sexual behaviour, change their negative attitudes, and focus on strategies that will maintain the quality of life of communities.

\section{LIMITATIONS}

- $\quad$ A test performance questionnaire would have been more appropriate to explore the participants' knowledge of sexuality education and reproductive health. As a result, the findings of the study only described the beliefs and sexual experiences of the participants.

- $\quad$ Some participants were uncomfortable talking about their sexual experiences in groups.

\section{CONCLUSION AND RECOMMENDA- TIONS}

More information about the quality of existing sexuality programmes should be obtained in order to provide the necessary help, that is, it is imperative to establish collaboration and partnership between the Department of Health and the Department of Education at national, provincial and regional levels in the country. It is unrealistic to expect school-teachers to adequately and effectively assist young people in understanding the broader social context of issues around HIV/AIDS and STIs without adequate training to do so. Opportunities for training and ongoing professional development should be increased (Synovitz et al. 2002:170).

Training opportunities to empower parents, community organisations and churches are fundamental. Several studies revealed that parents play a significant role as sexuality educators for their children; therefore support of parents by health professionals will assist them to attach value to providing sexuality education to their children. Preaching moral values, the use of condoms 
and contraception may delay the onset of intercourse and reduce the frequency of intercourse, promote safer sexual behaviour, reduce unwanted pregnancies, and the HIV/AIDS and STIs epidemic among youth in the country. Doctor Reverend Bishop Lekganyane conveyed a message of peace to his congregation by indicating the Zion Christian Church's belief "in abstinence until marriage. This is possible!" He further said, "my children, beware of the illness of HIV/AIDS. Respect your parents and listen to them. You will grow and mature to old age. Zionists love and nurture their children" (Lekganyane, 2003:10).

There is a need to establish peer education programmes by health professionals in the various organisations in the communities such as churches, schools, youth clubs, soccer clubs, youth groups supporting NAFCI, and Love Life. Health professionals should have an impact in all social contexts of their affiliation by creating opportunities for the youth to engage in frank discussions about sexuality. The youth should be able to decide whom they think they will be able to relate to freely and feel comfortable talking with.

There is a need to acknowledge that young people are sexual beings. The focus should shift from that of disease prevention, to looking at more socially-oriented health-enhancing behaviour such as teaching adolescents about sexual development, sexual behaviour and its possible negative outcomes, how to resist peer pressure to have sexual intercourse, sexual abuse and other nonsexual ways of showing affection. Australian research has indicated that sexuality education should also examine broader issues such as the social construction of sexuality, gender and power relations and other forms of discrimination (Mitchell et al. 2000:262-265).

\section{LIST OF REFERENCES}

BRINK, HI 1996: Fundamentals of research methodology for health care professionals. Cape Town. Juta.

BURNS, N \& GROVE, SK 1997: The practice of nursing research - conduct, critique and utilization; $4^{\text {th }}$ edition. Philadelphia: WB Saunders.

CRESSWELL, JW 1994: Research design, qualitative and quantitative approach. London: Sage.

DICKSON-TETTEH, K \& FOY, D 2001: The national adolescent friendly clinic initiative: Handbook of adolescent sexual and reproductive health care. Johannesburg: Colorpress.

EHLERS, VJ \& KHOZA, LB 2001: Reproductive health needs of adolescent mothers. Health and Hygiene, 12(8):2-4.

EHLERS, VJ 2003: Adolescent mothers knowledge and perceptions of contraceptives in Tshwane, South Africa. Health SA Gesondheid, 8(1):13-25.

KIRBY, D 1997: No easy answers. Research finding on programs to reduce teen pregnancy. Washington DC: National Campaign to prevent Teen Pregnancy.

LEHANA, TV \& VAN RHYN, L 2003: A phenomenological investigation of experiences of pregnancy by unmarried adolescents in Maseru. Health SA Gesondheid, 8(1):26-38.

LEKGANYANE, BE 2003: His Grace the right Reverend Bishop B E Lekganyane's sermon Easter 20 $0^{\text {th }}$ April 2003. ZCC Messenger, (56): 4-10.

LINCOLN, YS \& GUBA, EG 1985: Naturalistic inquiry. London: Sage. MINICHEILLO, V;ARONI, R; TIMEWELL, E \& ALEXANDER, L 1991 In-depth interviewing, researching people. Melbourne: Longman Cheshire.

MITCHELL, A; DEBBIE, O \& WATSON, J 2000: Talking sexual health: A national application of the health promoting school framework for HIV/AIDS education in secondary schools. Journal of School Health, 70(6):262-265.

NAHOM, D; WELLS, E; GILLMORE, MR; HOPPE, M; MORRISON, DM; ARCHIBALD, M; MUROWCHICK, E; WILSDON, A\& GRAHAM L 2001: Differences by gender and sexual experience in adolescent sexual behaviour. Journal of School Health, 70(4):153-159.

NETSHIKWETA, ML 1999: The problems associated with pregnancy amongst student nurses in the Northern Province. Unpublished M Cur dissertation. Pretoria: University of South Africa.

PELTZER, K 2001: Knowledge and practice of condom use among first year students at the University of the North, South Africa. Curationis, 24(1) :53-57

POLIT, DF \& HUNGLER, BP 1987: Nursing research: Principles and research. Philadelphia: JB Lippincott.

SILBERSCHMIDT, M \& RASCH, V 2001: Adolescent girls, illegal abortions and "sugar-daddies" in Dar es Salaam. Social Science and Medicine, $52: 1815-1826$.

SYNOVITZ, I; HERBERT, E; KELLEY, RM \& CARLSON, G 2002: Sexual knowledge of college students in a southern state. American Journal of Health Studies, 17(4): 163-173. WILCOX, AJ; BAIRD, DD \& WEINBERG, CR 1999: Time of implantation of the concept "us" and loss of pregnancy. New England Journal of Medicine, 340(23):1796-1799. 